\title{
Profile of cortisol, glycaemia, and blood parameters of American Bullfrog tadpoles Lithobates catesbeianus exposed to density and hypoxia stressors ${ }^{1}$
}

\author{
Patricia C. Teixeira², Danielle C. Dias², Guilherme C. Rocha ${ }^{3}$, Antônio M. Antonucci ${ }^{3}$, \\ Fernanda M. França ${ }^{3}$, Adriana S. Marcantonio ${ }^{4}$, Maria José T. Ranzani-Paiva ${ }^{3}$ \\ and Cláudia M. Ferreira ${ }^{3 *}$
}

\begin{abstract}
Teixeira P.C., Dias D.C., Rocha G.C., Antonucci A.M., França F.M., Marcantonio A.S., Ranzani-Paiva M.J.T. \& Ferreira C.M. 2012. Profile of cortisol, glycaemia, and blood parameters of American Bullfrog tadpoles Lithobates catesbeianus exposed to density and hypoxia stressors. Pesquisa Veterinária Brasileira 32(Supl.1):91-98. Setor de Patologia Veterinária, Faculdade de Veterinária, Universidade Federal do Rio Grande do Sul, Av. Bento Gonçalves 9090, Porto Alegre, RS 91540-000, Brazil. E-mail: claudia@pesca.sp.gov.br

The aim of this study was to evaluate alterations to the physiological profile (cortisol, glycaemia, and blood parameters) of Lithobates catesbeianus caused by the stressors density and hypoxia. The organisms were in the prometamorphosis stage and exposed to different tadpole densities: 1 tadpole/L (T1), 5 tadpoles/L (T2), and 10 tadpoles/L (T3) for 12 days. The blood was collected through the rupture of the caudal blood vessel and collected under normoxia (immediate collection) and hypoxia (after 15 minutes of air exposure) conditions. Cortisol levels rose on the fourth and eighth days of treatment and returned to basal levels by the end of the experiment. The stressor mechanisms tested did not affect glycaemia. White blood cells (total number of lymphocytes, neutrophils, and eosinophils) showed a significant difference at the twelfth day of the experiment when compared with the start of the experiment. We concluded that, under controlled conditions, a density of up to 10 tadpoles/L and air exposure for 15 minutes did not cause harmful physiological alterations during the experimental period. The answer to these stressors maybe was in another hormonal level (corticosterone).
\end{abstract}

INDEX TERMS: Frogculture, Lithobates catesbeianus, hematology, stress, cortisol.

\begin{abstract}
RESUMO.- [Perfil de cortisol, glicemia, e parâmetros sanguineos de girinos de rã-touro Lithobates catesbeianus expostos a diferentes densidades e hipóxia.] 0 objetivo deste estudo foi avaliar a resposta fisiológica (cortisol, glicemia e parâmetros sanguineos) de girinos de rã-touro (Lithobates catesbeianus) em diferentes densidades e após exposição aérea. Os animais utilizados no
\end{abstract}

\footnotetext{
${ }^{1}$ Received on August 15, 2012.

Accepted for publication on November 6, 2012.

${ }^{2}$ Centro de Aquicultura (CA), Universidade Estadual Paulista (Unesp), Via de Acesso Prof. Paulo Donato Castellane s/n, Jaboticabal, SP 14884900, Brazil. *Corresponding author: claudia@pesca.sp.gov.br

${ }^{3}$ Instituto de Pesca, Pólo Regional de Desenvolvimento Tecnológico dos Agronegócios (APTA), SAA, Av. Francisco Matarazzo 455, São Paulo, SP 05001900 , Brazil.

${ }^{4}$ Pólo Regional de Desenvolvimento Tecnológico dos Agronegócios (APTA), Av. Sagrado Corações s/n, Pindamonhangaba, SP 12411 020, Brazil.
}

experimento estavam entre os estágios 31 a 39, na fase de pró-metamorfose sendo testados 1 girino/L (Tratamento 1), 5 girinos/L (Tratamento 2) e 10 girinos/L (Tratamento 3), conduzidos em 3 réplicas simultâneas durante 12 dias. $\mathrm{O}$ sangue foi retirado por rompimento do vaso caudal na condição de Normóxia - N (tempo zero) e Hipóxia - H (tempo de 15 minutos de exposição ao ar). Foi observado um aumento nos valores de cortisol, aos 4 e 8 dias de exposição aérea retornando aos valores basais ao final do experimento, apesar de não haver diferenças significativas. A glicemia não apresentou diferenças significativas quanto aos estressores aplicados. Os parâmetros hematológicos da série branca, principalmente, o número de linfócitos, neutrófilos e eosinófilos mostraram diferença significativa aos 12 dias de experimentação quando comparados com o momento zero; concluindo-se que, em condições controladas, o adensamento de até 10 girinos/litro e a exposição 
aérea por 15 minutos não apresentou danos aos girinos de rã-touro durante o período experimental. 0 padrão de resposta a estes estímulos talvez seja expresso em outro nível hormonal (corticosterona).

TERMOS DE INDEXAÇÃO: Ranicultura, Lithobates catesbeianus, hematologia, estresse, cortisol.

\section{INTRODUCTION}

Frogculture is a popular commercial activity in South and Central Brazil, where 639 tons of these animals were bred in 2006, making Brazil the largest producer in the Americas (Ferreira et al. 2002, Dias et al. 2009). The main species used in commercial rearing is the American bullfrog, recently re-classified as Lithobates catesbeianus (Frost et al. 2006).

In any intensive rearing system, the occurrence of stressful conditions is inevitable. In particular, stress is a major problem in frog farms because it leads to several diseases. A failure of the rearing activity may be caused by inappropriate farming systems, inadequate physical, prophylactic, sanitary and food management, environmental changes or physical and chemical alterations of water conditions (Ferreira et al. 2002).

Toads and frogs are easily stressed animals (Duellman \& Trueb 1994, Ferreira et al. 2002, Wada 2008). In commercial rearing of bullfrogs, signs of stress include abortions, the emission of characteristic screams by females, and the lack of vocalisation by males in reproduction areas. These animals tend to remain hidden under water or protective shelters until they feel less threatened. In the fattening area, indicators of stress include the stacking of frogs in the corners of tanks, disoriented jumps, and the excessive appearance of skins in the humid areas of the pens. Sometimes a foamy mucus with a mild and characteristic odour can be seen. In tadpoles, a lack of appetite, apathy, and disoriented swimming can be seen (Ferreira et al. 2002). These responses to stress-inducing stimuli include alterations of the organic balance that jeopardise the health of the animal. The consequences are generally reduced growth, weight loss, decreased reproductive performance and decreased resistance to pathogens (Sapolsky 1993, Sapolsky et al. 2000).

Rearing healthy tadpoles and froglets is an imperative step for a successful bullfrog management. One of the most important factors that determine the quality of larval environments in amphibians is the density of individuals (Petranka 1989, Semlitsch \& Reichling 1989, Loman 2004), with high larval densities invariably leading to a number of detrimental effects, such as reductions in larval growth or size at metamorphosis (Semlitsch \& Caldwell 1982, Travis 1984, Altwegg \& Reyer 2003). "Chronic" stressors such as high larval density in amphibians can lead to chronically elevated baseline levels of glucocorticoid hormones in the larvae (Glennemeier \& Denver 2002b)

Biomarkers such as corticosterone, cortisol and glucose, together, with additional blood constituents, are used to evaluate stress. Although corticosterone appears more expressive in amphibians (Hayes et al. 1993, Kikuyama et al. 1993, Glennemeier \& Denver 2002a, Belden et al. 2003, 2010), the cortisol was also found in bullfrog tadpole and adult plasma in some studies (Krug et al. 1983, Denver et al. 2002, Wright et al. 2003) and the option to use cortisol as a biomarker is due to its easy and economic analysis when compared to others markers, such as corticosterone. Vertebrates generally respond to stressful stimuli in their environment with increases in adrenal glucocorticosteroids, cortisol or corticosterone, depending on the species (Romero 2002).

Glucose appears in amphibians investigations principally in energy balance regulation (Wang \& Chang 1994, Coppo et al. 2005). After the threat passes energy balance is restored through increased plasma glucocorticoid concentration, which stimulates appetite and reduces CRF expression via negative feedback (Sapolsky et al. 2000).

It is advisable to consider haematology in the diagnostic evaluation of any ill amphibian (Wright 2001). The use of leukocyte profiles to measure stress is exhibited by amphibians in some studies (Romanova \& Romanova 2003, Davis et al. 2008, Shutler et al. 2009). The immunity is diminished during stress response to redirect resources towards activities that are more immediately valuable to survival (Sapolsky et al. 2000).

The aim of this study was to investigate the possible alterations to levels of cortisol, glycaemia and other blood parameters in American bullfrog tadpoles L. catesbeianus exposed to different densities and hypoxia.

\section{MATERIALS AND METHODS}

In this experiment, we used American bullfrog tadpoles Lithobates catesbeianus in the prometamorphosis phase (GOSNER stage 36) showing an early emersion of the posterior hind limbs. The animals, acquired from a particular propriety $(10.32 \mathrm{~g}$ and $11.18 \mathrm{~cm})$, were transported to Reference Laboratory Unit for Pathology of Aquatic Organisms at the Fisheries Institute in São Paulo/Brazil, and acclimated in a $240 \mathrm{~L}$ tank for a period of seven days. They were then measured and distributed randomly in aquariums containing 20 tadpoles per unit using the densities of 1 tadpole/L (Treatment 1, control group), 5 tadpoles/L (Treatment 2) and 10 tadpoles/L (Treatment 3), with 20, 4 and 2L of water, respectively, where the animals remained for 12 days. Each treatment was conducted in triplicate.

For each of the tadpole densities, the organisms were submitted to the normoxia (immediate blood collection) and hypoxia (blood collection after 15 minutes of air exposition) conditions. The animals under normoxia condition were removed from the aquariums, placed in plastic boxes filled with water and immediately taken for blood collection. The animals under hypoxia conditions were removed from aquariums, placed inside humid plastic boxes where they were exposed to air for 15 minutes, and then taken for blood collection.

The blood samples were obtained after time intervals of 0 , 4,8 and 12 days. On day zero, before the animals were submitted to the different tadpole densities, 8 animals were sampled ( 4 under normoxia conditions and 4 under hypoxia conditions). For the samples collected on days 4 and 8, 6 animals/treatment were collected ( 3 under normoxia and 3 under hypoxia). For the final collection on day twelve, 18 animals/treatment were sampled (9 under normoxia and 9 under hypoxia). Thus, 98 animals were sampled during the experiment. The water levels were readjusted 
each time tadpoles were removed from the aquariums so that the density of the remaining animals was not altered.

Samples of blood was extracted through the rupture of the caudal blood vessel and collected using a micropipette with a heparin tip after the application of lidocaine as a local anesthetic. The collections were always conducted in the morning in order to allow for the circadian rhythm of the animals. One blood aliquot were used to cortisol (DSL ${ }^{\circledR}$ (Active-Cortisol EIA DSL10, Diagnostic System Labs USA) and glucose (Labtest ${ }^{\circledR}$ (Glicose PAP Liquiform, Labtest Diagnostica S.A.) analyses. Samples were centrifuged at $1006 \mathrm{x} g$ for 10 minutes to obtain plasma than were maintained on $-70^{\circ} \mathrm{C}$ freezer until analyse was completed. Other blood aliquots were used to determine haematological parameters: erythrocyte count (Er) in a Neubauer chamber; haematocrit (Ht); haemoglobin level $(\mathrm{Hb})$ and the calculation of the total haematometric index: Mean corpuscular volume (MCV); mean corpuscular haemoglobin concentration (MCHC); leukocyte differential (LDC) and total count (LTC); and total thrombocyte count (TTC) in extension stained with May-Grünwald-Giemsa. The red series (Er, Ht, Hb, MCV, and MCHC) and the white series (LDC, LTC, and TTC) were obtained only for day 0 and 12 .

The animals were kept in constant ventilation and fed commercial concentrate $(45 \%$ crude protein, $6 \%$ crude fibre, $9 \%$ ethereal extract) once per day in a ratio of $1 \%$ of live weight. The physico-chemical parameters of water were measured daily: temperature, electric conductivity, $\mathrm{pH}$, dissolved oxygen, ammonia, and nitrite. The hardness, alkalinity, and total ammonia were monitored every three days. The photoperiod was held constant at 12:12. Mortality was monitored daily.

A descriptive analysis of the variables was done to verify the differences between results of physiological and haematological data among the different treatments. The normality of the cortisol and glycaemia data was verified using the D'Agostino-Pearson test, and the homogeneity of variances among the treatments was verified using the Bartlett test. Because the number of observations was small and the samples were not normal, the three treatments were compared using the Kruskal-Wallis non-parametric test followed by the Student-Newman-Keuls test. For the haematological analysis, we used ANOVA followed by the Tukey test. The differences were considered significant when $p \leq 0.05$ (Zar 1999).

\section{RESULTS}

The water parameters analysed during experimentation did not vary between the different treatments or between the replicates. The mean obtained were: Temperature 23.16 $\pm 1.28 \mathrm{C}$; pH 7.43 \pm 0.21 ; Electric Conductivity $88.42 \pm 29.51 \mu \mathrm{S} / \mathrm{cm}$; Dissolved Oxygen $6.91 \pm 0.77 \mathrm{mg} / \mathrm{L}$; Total Ammonia $2.54 \pm 0.66 \mathrm{mg} / \mathrm{L} ; \mathrm{NH}_{3} 0.04 \mathrm{mg} / \mathrm{L}$; Nitrite $\left(\mathrm{NO}_{2}\right.$ ) $0.10 \mathrm{mg} / \mathrm{L}$; Total Hardness $18.42 \pm 6.34 \mathrm{mg} \mathrm{CaCO}_{3} / \mathrm{L}$; Total Alkalinity $25.53 \pm 11.69 \mathrm{mg} \mathrm{CaCO}_{3} / \mathrm{L}$.

Allowing the circadian rhythm of the animals (Licht et al. 1983, Jolivet-Jaudet et al. 1984, Thurmond et al. 1986, Herman 1992, Hopkins et al. 1997) the results showed: the cortisol values of Lithobates_catesbeianus tadpoles exposed to the stressors are presented in Table 1 . The mean values of cortisol obtained during the experiment ranged from 1.0 to $4.2 \mathrm{ng} / \mathrm{mL}$. Mean cortisol values ranging from 0.8 to $1.08 \mathrm{ng} / \mathrm{mL}$ were founded in a study with tadpoles from the same species (Wright et al. 2003); these values are smaller than values ranging from 12 to $22.3 \mathrm{ng} / \mathrm{mL}$ when studying prometamorphosis and climax animals, respectively (Krug et al. 1983). However, these authors reported qualitative
Table 1. Mean values of plasma cortisol (ng/mL) of Lithobates catesbeianus tadpoles exposed to the stressors density and hypoxia in the different days of collection

\begin{tabular}{|c|c|c|c|c|c|c|}
\hline \multirow[t]{2}{*}{$\begin{array}{l}\text { Time } \\
\text { (days) }\end{array}$} & \multicolumn{2}{|c|}{$\begin{array}{l}\text { Treatment } 1 \\
1 \text { tadpole/L }\end{array}$} & \multicolumn{2}{|c|}{$\begin{array}{l}\text { Treatment } 2 \\
5 \text { tadpoles/L }\end{array}$} & \multicolumn{2}{|c|}{$\begin{array}{c}\text { Treatment } 3 \\
10 \text { tadpoles/L }\end{array}$} \\
\hline & $(\mathrm{N})$ & (H) & $(\mathrm{N})$ & $(\mathrm{H})$ & $(\mathrm{N})$ & $(\mathrm{H})$ \\
\hline 0 & 1.0 & 2.3 & 1.0 & 2.3 & 1.0 & 2.3 \\
\hline 4 & 1.8 & 2.8 & 1.0 & 3.9 & 1.6 & 4.2 \\
\hline 8 & 2.6 & 1.5 & 2.5 & 2.3 & 1.5 & 1.6 \\
\hline 12 & 2.5 & 2.8 & 2.7 & 1.5 & 2.2 & 2.1 \\
\hline
\end{tabular}

(N) Normoxia = immediate blood collection, $(\mathrm{H})$ hypoxia = blood collected after 15 minutes of air exposure.

uncertainties regarding the analysed material, referring to it as "cortisol like". Studies with tadpoles of the same species and in the same developmental phase, found mean plasma cortisol values ranging from 2.14 to $5.0 \mathrm{ng} / \mathrm{mL}$ after exposing the animals to the stressors capture and hypoxia (Rocha et al. 2010). The Kruskal-Wallis test indicated that tadpole density had no effect on cortisol concentration. Consequently, data from all densities were analysed together and examined for differences between days. Therefore, the Kruskal-Wallis and the Student-Newman-Keuls tests were used. The results are presented in Figure 1. The data series of " 0 and 12 days" and " 4 and 8 days" did not show differences from each other; all others were significantly different $(\mathrm{p}<0.05)$.

The glycaemic values for Lithobates catesbeianus tadpoles exposed to stressor mechanisms are presented in Table 2. In a study on bullfrog tadpoles, glycaemic values ranging from 20 to $64 \mathrm{mg} / \mathrm{dL}$ (Wang \& Chang 1994), values ranging

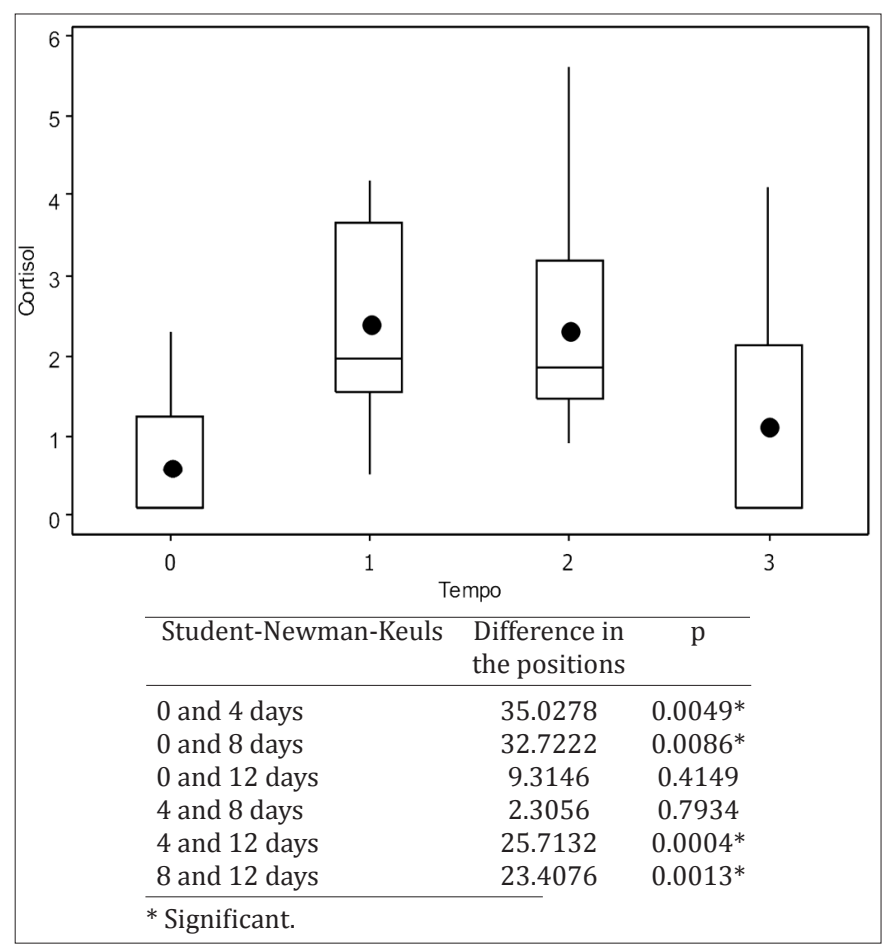

Fig.1. Plasma Cortisol mean (๑) and median values on collection days $0,4,8$ and 12, data clustered by time period, obtained during experimentation with Lithobates catesbeianus tadpoles, and results of the non-parametric Student Newman-Keuls test 
Table 2. Mean values of glucose (mg/dL) of Lithobates catesbeianus tadpoles exposed to the stressors density and hypoxia in the different days of collection

\begin{tabular}{|c|c|c|c|c|c|c|}
\hline \multirow[t]{2}{*}{$\begin{array}{l}\text { Time } \\
\text { (days) }\end{array}$} & \multicolumn{2}{|c|}{$\begin{array}{l}\text { Treatment } 1 \\
1 \text { tadpole/L }\end{array}$} & \multicolumn{2}{|c|}{$\begin{array}{l}\text { Treatment } 2 \\
5 \text { tadpoles/L }\end{array}$} & \multicolumn{2}{|c|}{$\begin{array}{c}\text { Treatment } 3 \\
10 \text { tadpoles/L }\end{array}$} \\
\hline & $(\mathrm{N})$ & $(\mathrm{H})$ & (N) & $(\mathrm{H})$ & (N) & $(\mathrm{H})$ \\
\hline 0 & 13.80 & 20.59 & 13.80 & 20.59 & 13.80 & 20.59 \\
\hline 4 & 10.98 & 16.81 & 9.31 & 29.03 & 14.53 & 30.87 \\
\hline 8 & 13.18 & 24.60 & 16.81 & 17.78 & 11.89 & 22.73 \\
\hline 12 & 17.25 & 25.51 & 16.75 & 24.21 & 19.92 & 25.18 \\
\hline
\end{tabular}

(N) Normoxia = immediate blood collection, $(\mathrm{H})$ hypoxia = blood collected after 15 minutes of air exposure.

from 45 to $54 \mathrm{mg} / \mathrm{dL}$ (Coppo et al. 2005) and values ranging from 49.33 to $104.33 \mathrm{mg} / \mathrm{dL}$ (Rocha et al. 2010). In the present study, the values found were lower, ranging from 9.31 to $30.87 \mathrm{mg} / \mathrm{dL}$. The glycaemic data were analysed using the non-parametric Kruskal-Wallis test. As in the cortisol analysis, there were no statistical differences $(p<0.05)$ between the treatments (tadpole density), and the data were consequently clustered and analysed in relation to time. However, no significant differences were found in plasma glucose values over time in Figure 2.

Complementing the physiological traits of cortisol and glycaemia levels, some haematological indicators were also used to identify stress in American bullfrog tadpoles. The red series haematological parameters for animals exposed to the stressor mechanisms are presented in Table 3. In the present study, mean values for the various parameters were Ht $18.33 \pm 2.51 \%$; Er 25.43 $\pm 3.6810^{4}$ / $\mathrm{mm}^{3} ; \mathrm{Hb} 3.67 \pm 0.49 \mathrm{~g} / 100 \mathrm{~mL} ; \mathrm{MCV}$ 816.05 $\pm 111.71 \mathrm{fL}$,

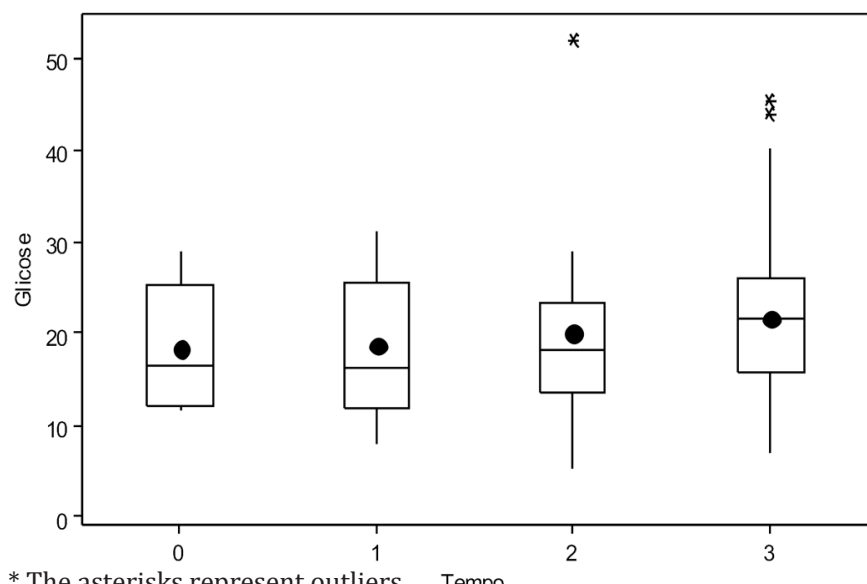

* The asterisks represent outliers. Tempo

Fig.2. Glucose mean ( $\bullet$ and median values on collection days $0,4,8$ and 12 , data clustered by time period, obtained during experimentation with Lithobates catesbeianus tadpoles.

and MCHC 22.81 $\pm 3.76 \%$. Values about Ht 30,1 $\pm 5,4 \%$; Er $42 \pm 710^{4} / \mathrm{mm}^{3} ; \mathrm{Hb} 6,8 \pm 1,48 \mathrm{~g} / 100 \mathrm{~mL} ; \mathrm{MCV} 709 \pm 136 \mathrm{fL}$; MCHC 23,3 $\pm 2,7 \%$ (Coppo et al.2005) and values about Ht $22,5 \pm 5 \%$; Hb 4,7 $\pm 0,9 \mathrm{~g} / 100 \mathrm{~mL}$ (Cathers et al. 1997). There were not significant differences between the treatments in the different collection days corroborating the reports from another study (Rocha et al. 2010) on the same species of tadpoles.

The mean value and standard error of thrombocytes of the tadpoles submitted to the stressor mechanisms were $1950.10 \pm 713.23$ thrombocytes $/ \mathrm{mm}^{3}$, showing no difference between the treatments.

Table 3. Mean values and standard error of red series hematological parameters for Lithobates catesbeianus tadpoles exposed to the stressors density and hypoxia in the different days of collection

\begin{tabular}{|c|c|c|c|c|c|c|}
\hline & & $\begin{array}{l}\text { Erythrocytes } \\
\left(10^{4} / \mathrm{mm}^{3}\right)\end{array}$ & $\begin{array}{c}\text { Hematocrit } \\
(\%)\end{array}$ & $\begin{array}{l}\text { Hemoglobin } \\
\left(\mathrm{g} / 100 \mathrm{~mL}^{1}\right)\end{array}$ & $\begin{array}{l}\text { MCV } \\
\text { (fL) }\end{array}$ & $\begin{array}{c}\text { MCHC } \\
(\%)\end{array}$ \\
\hline \multirow{4}{*}{0} & $\mathrm{ZM}(\mathrm{N})$ & $29.63 \pm 5.28$ & $22.67 \pm 3.69$ & $3.96 \pm 0.99$ & $770.89 \pm 40.55$ & $18.66 \pm 1.60$ \\
\hline & $\mathrm{ZM}(\mathrm{H})$ & $21.88 \pm 2.87$ & $18.00 \pm 0.00$ & $3.49 \pm 0.26$ & $1125.00 \pm 0.00$ & $17.19 \pm 0.00$ \\
\hline & $\mathrm{T} 1(\mathrm{~N})$ & * & $13.00 \pm 0.00$ & $5.04 \pm 0.55$ & $*$ & $32.18 \pm 0.00$ \\
\hline & $\mathrm{T} 1(\mathrm{H})$ & $*$ & $14.00 \pm 3.27$ & $3.31 \pm 0.25$ & * & $26.92 \pm 5.02$ \\
\hline \multirow{5}{*}{ 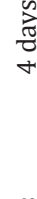 } & $\mathrm{T} 2(\mathrm{~N})$ & * & $17.75 \pm 2.66$ & $2.75 \pm 0.25$ & * & $17.31 \pm 2.11$ \\
\hline & $\mathrm{T} 2(\mathrm{H})$ & $*$ & $20.00 \pm 0.58$ & $3.42 \pm 0.44$ & $*$ & $16.64 \pm 1.81$ \\
\hline & T3 (N) & $*$ & $16.00 \pm 1.53$ & $3.52 \pm 0.22$ & $*$ & $22.29 \pm 1.74$ \\
\hline & T3 (H) & * & $13.00 \pm 2.45$ & $4.30 \pm 0.09$ & * & $44.09 \pm 0.00$ \\
\hline & $\mathrm{T} 1(\mathrm{~N})$ & * & $16.00 \pm 3.27$ & $4.66 \pm 0.62$ & * & $32.94 \pm 3.10$ \\
\hline & $\mathrm{T} 1(\mathrm{H})$ & * & $18.00 \pm 1.63$ & $3.46 \pm 0.31$ & * & $20.90 \pm 0.90$ \\
\hline \multirow{5}{*}{$\begin{array}{l}\vec{J} \\
\infty\end{array}$} & $\mathrm{T} 2(\mathrm{~N})$ & $*$ & $16.50 \pm 2.86$ & $3.43 \pm 0.62$ & * & $13.38 \pm 0.00$ \\
\hline & $\mathrm{T} 2(\mathrm{H})$ & $*$ & $19.00 \pm 2.52$ & $3.60 \pm 0.26$ & $*$ & $20.05 \pm 4.26$ \\
\hline & T3 (N) & * & $15.50 \pm 0.00$ & $4.80 \pm 1.04$ & * & $23.40 \pm 5.08$ \\
\hline & T3 (H) & * & $15.50 \pm 2.04$ & $3.17 \pm 0.37$ & * & $23.40 \pm 5.08$ \\
\hline & $\mathrm{T} 1(\mathrm{~N})$ & $26.50 \pm 4.79$ & $13.00 \pm 1.52$ & $3.30 \pm 0.57$ & $563.62 \pm 112.29$ & $32.30 \pm 9.02$ \\
\hline & $\mathrm{T} 1(\mathrm{H})$ & $24.06 \pm 2.03$ & $18.07 \pm 1.98$ & $3.27 \pm 0.31$ & $747.74 \pm 72.45$ & $19.69 \pm 1.58$ \\
\hline \multirow{5}{*}{ 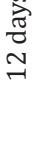 } & $\mathrm{T} 2(\mathrm{~N})$ & $26.70 \pm 3.27$ & $14.75 \pm 1,66$ & $4,41 \pm 0.36$ & $672.05 \pm 125.09$ & $29.78 \pm 3.14$ \\
\hline & $\mathrm{T} 2(\mathrm{H})$ & $24.11 \pm 4.79$ & $23.83 \pm 2,95$ & $3,63 \pm 0.52$ & $921.55 \pm 127.88$ & $16.66 \pm 0.98$ \\
\hline & T3 (N) & $24.25 \pm 2.89$ & $18.86 \pm 3,22$ & $3,50 \pm 0.49$ & $902.90 \pm 171.88$ & $20.29 \pm 3.10$ \\
\hline & T3 $(\mathrm{H})$ & $26.36 \pm 3.54$ & $17.50 \pm 2,56$ & $3,80 \pm 0.40$ & $824.63 \pm 131.83$ & $27.92 \pm 6.88$ \\
\hline & $\mathrm{F}$ & $0.22^{\mathrm{NS}}$ & $0.85^{\mathrm{NS}}$ & $0.75^{\mathrm{NS}}$ & $0.62^{\mathrm{NS}}$ & $0.83^{\mathrm{NS}}$ \\
\hline
\end{tabular}

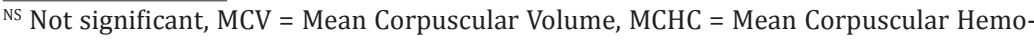
globin Concentration; $\mathrm{ZM}=$ zero moment, $\mathrm{T} 1=1$ tadpole $/ \mathrm{L}, \mathrm{T} 2=5$ tadpoles $/ \mathrm{L}, \mathrm{T} 3=10$ tadpoles $/ \mathrm{L},(\mathrm{N})$ Normoxia $=$ immediate blood collection, $(\mathrm{H})$ hypoxia $=$ blood collected after 15 minutes of air exposure. * The red series completed (Er, Ht, Hb, MCV, and $\mathrm{MCHC}$ ) were obtained only for day 0 and 12 . 
Table 4. Mean values and standard error of white series hematological parameters for Lithobates catesbeianus tadpoles exposed to the stressors density and hypoxia in the zero time and twelfth day of the experiment

\begin{tabular}{|c|c|c|c|c|c|c|c|c|c|c|c|c|c|}
\hline \multirow{4}{*}{$\frac{\pi}{0}$} & \multirow{3}{*}{$\mathrm{ZM}(\mathrm{N})$} & \multicolumn{2}{|c|}{ Leucocytes } & \multicolumn{2}{|l|}{ Lymphocytes } & \multicolumn{2}{|c|}{ Neutrophils } & \multicolumn{2}{|c|}{ Basophils } & \multicolumn{2}{|c|}{ Eosinophils } & \multicolumn{2}{|c|}{ Monocytes } \\
\hline & & & & & $\%$ & & $\%$ & & $\%$ & & $\%$ & & 8 \\
\hline & & $8177.4 \pm 2352.0$ & abs & 0 & & & & & & 61 & & & \\
\hline & $\mathrm{ZM}(\mathrm{H})$ & & & & $\%$ & & $\%$ & & $\%$ & & $\%$ & & \\
\hline \multirow{15}{*}{$\begin{array}{l}\stackrel{n}{\vec{d}} \\
\stackrel{d}{v}\end{array}$} & & 1 & abs & 95 & Abs & 36 & abs & 12 & abs & 338 & abs & & \\
\hline & $\mathrm{T} 1(\mathrm{~N})$ & & & & $\%$ & & $\%$ & & 0 & & $\%$ & & \\
\hline & & $12937.7 \pm 3$ & abs & 1271 & Abs & 12 & abs & 33 & abs & & abs & & \\
\hline & $\mathrm{T} 1 \mathrm{H}$ & & & & $\%$ & & $\%$ & & 0 & & $\%$ & & \\
\hline & & $14473.2 \pm 2515.2$ & abs & 1382 & Abs & 461 & abs & 77. & abs & $0^{\mathrm{b}}$ & abs & & $a b$ \\
\hline & $\mathrm{T} 2(\mathrm{~N})$ & & & & $\%$ & 4. & $\%$ & 1. & $\%$ & & $\%$ & & \\
\hline & & $8563.2 \pm 1$ & abs & 7940 & Abs & 361 & abs & 122. & abs & 138. & abs & 0. & $a b$ \\
\hline & $\mathrm{T} 2(\mathrm{H})$ & & & & $\%$ & 2.2 & $\%$ & 0.5 & $\%$ & & $\%$ & 0. & \\
\hline & & $11177.2 \pm 2$ & abs & 10727 & Abs & 190 & abs & 102. & abs & 156. & abs & 0. & al \\
\hline & T3 $(\mathrm{N}$ & & & & $\%$ & 1.5 & $\%$ & 2.3 & $\%$ & 0. & $\%$ & 0.3 & \\
\hline & & $8907.5 \pm$ & abs & 845 & Abs & 163. & abs & 154 & abs & 92.2 & abs 2 & 0.1 & $\mathrm{al}$ \\
\hline & & & & & $\%$ & 3 & $\%$ & 09 & $\%$ & 1.5 & $\%$ & 0. & \\
\hline & & $92.2 \pm$ & abs & 1362 & Abs & $517.3 \pm 106.0$ & abs & $136.4 \pm 68.2$ & abs & $187.0 \pm 44.8^{\mathrm{b}}$ & abs 2 & $25.2 \pm 15.1$ & $\mathrm{al}$ \\
\hline & $\mathrm{F}$ & & & & $\%$ & $2.1^{* *}$ & $\%$ & $4.3^{\mathrm{NS}}$ & $\%$ & $6.7^{* * *}$ & $\%$ & $0.3^{\mathrm{NS}}$ & $\%$ \\
\hline & & $0.9^{\mathrm{NS}}$ & abs & $1.0^{\mathrm{NS}}$ & Abs & $2.1^{\mathrm{NS}}$ & Abs & $0.8^{\mathrm{NS}}$ & abs & $4.2^{* *}$ & abs & $1.3^{\mathrm{NS}}$ & \\
\hline
\end{tabular}

$\overline{\mathrm{MZ}}=$ zero moment, $\mathrm{T} 1=1$ tadpole $/ \mathrm{L}, \mathrm{T} 2=5$ tadpoles $/ \mathrm{L}, \mathrm{T} 3=10$ tadpoles/L, $(\mathrm{N})$ Normoxia $=$ immediate blood collection, $(\mathrm{H})$ hypoxia = blood collected after 15 minutes of air exposure. Mean followed by the same letters, in the column don't differ statiscally by Tukey test $\mathrm{p}<0.05$ of probability.

The haematological parameters of the white series for animals exposed to the stressor mechanisms are presented in Table 4. In the present study, the leukocyte cell type most abundant in L. catesbeianus individuals making the majority (i.e nearly $80 \%$ combined) of WBCs were lymphocytes and neutrophils, while the eosinophils, basophils and monocytes were more scarce, corroborating the results of theses authors (Cathers et al. 1997, Ferreira et al. 2003, Thrall 2004, França et al. 2008, Dias et al. 2009). There were significant differences between the treatments on different collection days for neutrophil percentage, and extremely significant differences for lymphocyte and eosinophil percentages. However, when the absolute numbers of these cells was considered, only the eosinophils showed a significant difference.

\section{DISCUSSION}

Water quality is probably the most critical component of amphibian housing. This is especially true for larval amphibians; although adults, including terrestrial species, are also affected by poor water quality which such changes can have disastrous effects on stable amphibian colonies (DeNardo 1995, Demichelis et al. 2001, Godfrey \& Sanders 2004). However, the results showed that the physic-chemical water parameters inside the aquariums remained within the standards required to conduct tests with amphibians and according another study (Culley Jr 1991) were considered good using the standards for farming practices of these aquatic organisms

Cortisol results, in the present study, from the tested stressor stimuli were not consistent with the classic stress response model; that is, an increase in glucocorticoid levels after exposure to a stressor stimulus. The complex interpretation of results about cortisol is due to the nature of the stressor, and the magnitude and duration of the stress response. Additionally, they may have been a result of the stu- died species (Moberg 2000, Wada 2008). It has been shown that glucocorticoids in Amphibia present a specific pattern to distinct species (Crespi \& Denver 2004a, 2005). Specifically in the premetamorphosis and prometamorphosis stages, the synthesis of corticosteroids varies depending on the presented challenge (stressor stimulus) and on the organism's life cycle (Belden et al. 2003, Crespi \& Denver 2005). Cortisol acts synergistically with an increase in hormonal levels in the thyroid, which accelerates metamorphosis (Hayes et al.1993, Kikuyama et al. 1993, Wright et al. 1994).

A density of 1 tadpole/L is recommended because tadpole performance (growth and survival) is better at this density, and it provides a good cost-benefit ratio for commercial production (Ferreiraet al. 2002). The data analysis per treatment showed that cortisol levels in 1 tadpole/L (control group) remained under the general average. Although 10 tadpoles/L group did not differ statistically from the 1 tadpole/L group in this study, it was observed that the animals kept in the highest density (10 tadpoles/L) started the metamorphosis process $(70 \%$ of samples) corroborating with the studies (Denver 1993, 1997, 1998, Denver et al. 1998) that the low level of water may cause an acceleration of tadpole metamorphosis.

Catecholamines are the first hormones released in fish exposed to hypoxia, with the highest levels occurring about 30 seconds after the perception of the stressor (Rotllant \& Tort 1997). Then, a simultaneous increase of cortisol levels occurs, with the highest concentrations of the hormone being detected 30 minutes after the disturbance. In the present study the cortisol values of animals submitted to hypoxia did not differ from the animals in normoxia corroborating the reports from another study (Rocha et al. 2010) on the same species of tadpole.

The same way, glucose results, in the present study, from the tested stressor stimuli were not consistent with 
the classic stress response model. Glycaemia is one of the most used stress indicators of secondary physiological responses, where it increases in the presence of any stressor in order to meet the higher energy demand needed to escape or to confront an adverse situation (Heinrichs \& Richard 1999, Richard et al. 2002, Sapolsky et al. 2000, Carr 2002, Crespi \& Denver 2005) Although there are several studies about blood glucose levels on amphibians, these are not easily interpreted due to variations of factors such as feeding, life stage, and even collection methods (Herman 1992).

In aquaculture, stocking density is an important factor influencing food ingestion and is species-specific. Food absorption can also be influenced by social interactions increased by spatial restriction and competition for food (Wendelaar Bonga 1997, Flores-Nava \& Gasca-Leyva 1997, Crespi \& Denver 2004a,b, 2005). Stress hormones are important in the energy balance during the development of amphibians (Hayes et al. 1993, Glennemeier \& Denver $2002 b)$. Studies show neuroendrocrine control of corticotropin-releasing factor (CRF) and of glucocorticoids in response to the stress of feeding behaviour, where ingested food is regulated differently in the different stages of life of these animals (Richard \& Timofeeva 2002, Crespi \& Denver 2004a,b, 2005). An adaptation to stress can occur in chronic response therefore, results in lower GC responses (Wenderlaar Bonga 1997, Moberg 2000, Romero 2004). This could explain the glycaemic results in this study, where animals showed a tendency to adapt over time.

About the results of red blood series, the differences observed may be influenced by factors including stage of development (larval versus adult), age, gender, reproductive status, and environmental variables (wild versus captive, food and water availability, temperature, photoperiod, altitude) (Allender \& Fry 2008). Thrombocytes are easily confused with lymphocytes (Penha et al. 1996, Allender \& Fry 2008) maybe the reason about few studies investigating this cell. About the results of white blood series, some studies suggest that stressors usually suppress immune system. A decrease in leukocyte populations, indicating susceptibility to infections was found in metamorphosing individuals (Kolias 1984, Ussing \& Rosenkilde 1995). Specifically, lymphocytes and neutrophils were demonstrated to decrease midclimax of metamorphosis (Ussing \& Rosenkilde 1995). The proportion of neutrophils increases while the proportion of lymphocytes decreases (Forbes, McRuer \& Shutler 2006). However, in the present study, the stressor mechanisms promoted an increase in the percentage of lymphocytes. Reductions in neutrophils counts in amphibians were observed in some studies corroborating the present one that show a decrease in eosinophils numbers and percentage (Woodhams et al. 2007, Belden \& Kiesecker 2005).

An interaction between immune and endocrine functions promoting homeostasis when facing stressful conditions (Wick et al. 1993, Gentz 2007). Agents are released during the stress process, causing not only an increase or decrease in the immune response, but also a redistribution of immune cells throughout the entire body (Forbes et al. 2006, Davis et al. 2008). The metamorphosis involves a reorganization of the amphibian immune system (Rollins-Smith et al. 1997) and the present study had metamorphosed animals in the high density. It is important to note that these physiological alterations consume energy and, from the moment that these stimuli become chronic, there is a tendency for the tertiary effects of stress to occur, i.e., a decrease in resistance and problems related to growth and development of these animals. These effects direct relate not only with the commercial rearing of American bullfrog Lithobates catesbeianus but also with other Anura subjected to the same conditions in nature.

The fact that no significant alterations were observed in the evaluated parameters, cortisol and glucose, may indicate that the stressor stimuli were not adequate to increase the values of these biological markers. Alternatively, a larger response pattern to these stimuli may have been expressed in the levels of an unmeasured hormone (corticosterone). Additional studies are necessary to complement the information about stress physiology and its biomarkers for L. catesbeianus, especially for intensive rearing systems.

Acknowledgments.- To FAPESP, for the financial support (Project 05/53070-0). To Instituto de Pesca de São Paulo and CA-Unesp, for the assistance and academic support.

\section{REFERENCES}

Allender M.C. \& Fry M.M. 2008. Amphibian hematology. Vet. Clin. Exotic Anim. 11:463-480.

Altwegg R. \& Reyer H.U. 2003. Patterns of natural selection on size at metamorphosis in water frogs. Evolution 57:872-882.

Belden L.K., Moore I.T., Mason R.T., Wingfield J.C. \& Blaustein A.R. 2003. Survival, the hormonal stress response and UV-B avoidance in Cascades Frog tadpoles (Rana catesbeiana) exposed to UV-B radiation. Functional Ecology 17:409-416.

Belden L.K. \& Kiesecker J.M. 2005. Glucocorticosteroid hormone treatment of larval treefrogs increases infection by Alaria sp trematode cercariae. J. Parasitol. 91:686-688.

Belden L.K., Wingfield J.C. \& Kiesecker J.M. 2010. Variation in the hormonal stress response among larvae of three amphibian species. J. Exp. Zoology 313A (8): 524-531.

Carr J.A. 2002. Stress, neuropeptides, and feeding behavior: a comparative perspective. Integr. Comp. Biol. 42:582-590.

Cathers T., Lewbart G.A., Correa M. \& Stevens J.B. 1997. Serum chemistry and hematology values for anesthetized American bullfrogs (Rana catesbeiana). J. Zoo Wildl. Med. 28:171-174.

Coppo J.A., Mussart N.B., Fioranelli S.A. \& Zeinsteger P.A. 2005. Blood and urine physiological values in captive bullfrog Rana catesbeiana (Anura: Ranidae). Analecta Veterinaria 25:15-17.

Crespi E.J. \& Denver R.J. 2004a. Roles of corticotropin-releasing factor, neuropeptide-y, and corticosterone in the regulation food intake in $\mathrm{Xe}$ nopus laevis. J. Neuroendocrinol. 16:279-288.

Crespi E.J. \& Denver R.J. 2004b. Ontogeny of corticotropin-releasing factor on locomotion and foraging in the western spadefoot toad, Spea hammondii. Hormone and Behavior 46:399-410.

Crespi E.J. \& Denver R.J. 2005. Roles of stress hormones in food intake regulation in anuran amphibians throughout the life cycle. Comp. Biochem. Physiol. A 141:381-390.

Culley Jr D.D. 1991. Bullfrog culture, p.185-205. In: Neimann-Sorensen A., Tribe D.E. \& Nash C.E. (Eds), Production of Aquatic Animals: crustaceans, mollusks, amphibians and reptiles. Elsevier - World Animal Science, Amsterdam, C4.

Davis A.K., Maney D.L. \& Maerz J.C. 2008. The use of leukocyte profiles to 
measure stress in vertebrates: a review for ecologists. Functional Ecology 22:760-772.

DeNardo D. 1995. Fish, amphibians and reptiles: amphibians as laboratory animals. Ilar Journal 37(4): 173-181.

Denver R.J. 1993. Acceleration of anuran amphibian metamorphosis by corticotropin-releasing hormone-like peptides. Gen. Comp. Endocrinol. 91:38-51.

Denver R.J. 1997. Environmental stress as a developmental cue: corticotrophin-releasing hormone is a proximate mediator of adaptive phenotypic plasticity in amphibian metamorphosis. Hormone and Behavior 31:169-179.

Denver R.J. 1998. Hormonal correlates of environmentally induced metamorphosis in the Western spadefoot toad, Scaphiopus hammondii. Gen. Comp. Endocrinol. 110:326-336.

Denver R.J., Mirhadi N. \& Phillips M. 1998. Adaptive plasticity in amphibian metamorphosis: response of Scaphiopus hammondii tadpoles to habitat esiccation. Ecology 79:1859-1872.

Denver R.J., Boorseand G.C. \& Glennemeier K.A. 2002. Endocrinology of complex life cycles: amphibians, p.469-513. In: Pfaff D., Arnold A., Etgen A., Fahrbach S., Moss R. \& Rubin R. (Eds), Hormones, Brain and Behavior. Vol.2. Academic Press, San Diego.

Demichelis S.O., De La Torre F.R., Ferrari L., Garcia M.E. \& Salibian A. 2001. Tadpoles assay: Its application to a water toxicity assessment of a polluted urban river. Environ. Monit. Assess. 68:63-73.

Dias D.C., Stéfani M.V., Ferreira C.M., França F.M., Ranzani-Paiva M.J.T. \& Santos A.A. 2009. Haematologic and immunologic parameters of bullfrogs, Lithobates catesbeianus, fed probiotics. Aquacult. Res. 41(7):1064-1071.

Duellman W.E. \& Trueb L. 1994. Biology of Amphibians. Johns Hopkins University Press, Baltimore, MD.

Ferreira C.M., Pimenta A.G.C. \& Paiva Neto J.S. 2002. Introdução à ranicultura. Bolm Téc. Inst. Pesca 33:1-14.

Ferreira C.M., Guimarães H.M.B., Ranzani-Paiva M.J.T., Soares S.R., Riviero D.H.R.F. \& Saldiva P.H.N. 2003. Hematological markers of copper toxicity in Rana catesbeiana tadpoles (Bullfrog). Revta Bras. Toxicol. 16(2):8388.

Flores-Nava A. \& Gasca Levya E. 1997. Use of artificial grazing substrates in bullfrog tadpole culture. Aquaculture 152:91-101.

Forbes M.R., McRuer D.L. \& Shutler D. 2006. Whiteblood cell profiles of breeding American toads (Bufo americanus) relative to sex and body size. Comp. Clin. Pathol. 15:155-159.

França F.M., Dias D.C., Teixeira P.C., Marcantônio A.S., Stéfani M.V., Antonucci A.M., Rocha G.C., Ranzani-Paiva M.J.T. \& Ferreira C.M. 2008. Efeito do probiótico Bacillus subtilis no crescimento, sobrevivência e fisiologia de rãs-touro (Rana catesbeiana). Bolm Inst. Pesca 34(3):403-412.

Frost D.R., Grant T., Faivovich J., Bain R.H., Haas A., Haddad C.F.B., De Sa R., Channing A., Wilkinson M., Donnllan S.C., Raxworthy C.J., Campbell J.A., Blotto B.L., Moler P., Drewes R.C., Nussbaum R.A., Lynch J.D., Green D.M. \& Wheeler W.C. 2006. The amphibian tree of life. Bulletin of American Museum of Natural History 297:1-370.

Gentz E.J. 2007. Medicine and surgery of amphibians. Ilar Journal 48:255259.

Glennemeier K.A. \& Denver R.J. 2002a. Small changes in whole-body corticosterone content affect larval Rana pipiens fitness components. Gen. Comp. Endocrinol. 127:16-25.

Glennemeier K.A. \& Denver R.J. 2002b. Role for corticoids in mediating the response of Rana pipiens tadpoles to intraspecific competition. J. Exp. Zoology 292:32-40.

Godfrey R.C. \& Sanders E.W. 2004. Effect of water hardness on oocyte quality and embryo development in the African clawed frog (Xenopus laevis). Comp. Med. 54:170-175.

Gosner K.L. 1960. A simplified table for standing anuran embryos and larvae with notes on identification. Herpetologica, Johnson, 16:183-190.

Hayes T.B., Chan R. \& Licht P. 1993. Interactions of temperature and steroids on larval growth, development, and metamorphosis in a toad (Bufo boreas). J. Exp. Zoology 266:206-215.
Heinrichs S.C. \& Richard D. 1999. The role of corticotropin-releasing factor and urocortin in the modulation of ingestive behavior. Neuropeptides 33:350-359.

Herman C.A. 1992. Endocrinology, p.40-54. In: Feder M.E. \& Burggren W.W. (Eds), Environmental Physiology of the Amphibians. University of Chicago Press, Chicago.

Hopkins W.A., Mendonca M.T. \& Congdon J.D. 1997. Increased circulating levels of testosterone and corticosterone in southern toads, Bufo terrestris, exposed to coal combustion waste. Gen. Comp. Endocrinol. 108:237-246.

Jolivet-Jaudet G., Inoue M., Takada K. \& Ishii S. 1984. Circannual changes in corticosterone plasma levels and binding of corticosterone to plasma in Bufo japonicus formosus. Zool. Sci. 1:317-326.

Kolias G.V. 1984. Immunologic aspects of infectious diseases, p.661-691. In: Hoff G., Frye F. \& Jaconson E. (Eds), Diseases of Amphibians and Reptiles. Plenum Press, New York.

Kikuyama S., Kawamura K., Tanaka S. \& Yamamoto K. 1993. Aspects of amphibian metamorphosis: Hormonal Control. International Rev. Cytology 145:105-148.

Krug E.C., Honn K.V., Battista J. \& Nicoll C.S. 1983. Corticosteroids in serum of Rana catesbeiana during development and metamorphosis. Gen. Comp. Endocrinol. 52:232-241.

Licht P., McCreery B.R., Barnes R. \& Pang R. 1983. Seasonal and stress related changes in plasma gonadotropins, sex steroids, and corticosterone in the bullfrog, Rana catesbeiana. Gen. Comp. Endocrinol. 50:124-145.

Loman J. 2004. Density regulation in tadpoles of Rana temporaria: a full pond field experiment. Ecology 85:1611-1618.

Moberg G.P. 2000. Biological responses to stress: implications for animal welfare, p.1-22. In: Moberg G.P. \& Mench J.A. (Eds), The Biology of Animal Stress: basic principles and implications for animal welfare. CABI Publishing, Wallingford.

Penha M.L., Dias J.L.C. \& Malucelli B.E. 1996. Influence of low environmental temperature on the phagocytic activity of bullfrog (Rana catesbeiana) thrombocytes. Braz. J. Vet. Res. Anim. Sci. 33(1):15-18.

Petranka J.W. 1989. Density-dependent growth and survival of larval Ambystoma: evidence from whole-pond manipulations. Ecology 70:17521767.

Richard D., Lin Q. \& Timofeeva E. 2002. The corticotropin-realising actor family of peptides and CRF receptors: their roles in the regulation of energy balance. Eur. J. Pharmacol. 44:189-197.

Rocha G.C., Ferreira C.M., Teixeira P.C., Dias D.C., França F.M., Antonucci A.M., Marcantônio A.S. \& Lauretto M. 2010. Physiological response of American bullfrog tadpoles to stressor conditions of capture and hypoxia. Pesq. Vet. Bras. 30(10):891-896.

Rollins-Smith L.A., Barker K.S. \& Davis A.T. 1997. Involvement of glucocorticoids in the reorganization of the amphibian immune system at metamorphosis. Dev. Immunol. 5:145-152.

Romanova E.B. \& Romanova O.Y. 2003. Peculiarities of leukocytic formula of peripheral blood of green frogs under conditions of anthropogenic load. J. Evolutionary Biochem. Physiol. 39:480-484.

Romero L.M. 2002. Seasonal changes in plasma glucocorticoid concentrations in free-living vertebrates. Gen. Comp. Endocrinol. 128:1-24.

Romero L.M. 2004. Physiological stress in ecology: lessons from biomedical research. Ecology and Evolution, 19(5):249-255.

Rotllant J. \& Tort L. 1997. Cortisol and glucose responses after acute stress by net handling in the sparid red porgy previously subjected to crowding stress. J. Fish Biol. 51:21-28.

Sapolsky R.M., Romero L.M. \& Munck A.U. 2000. How do glucocorticoids influence stress responses? Integrating permissive, suppressive, stimulatory, and preparative actions. Endocrine Reviews 21: 55-89.

Semlitsch R.D. \& Caldwell J.P. 1982. Effects of density on growth, metamorphosis, and survivorship in tadpoles of Scaphiopus holbrooki. Ecology 63:905-911.

Semlitsch R.D. \& Reichling S.B. 1989. Density-dependent injury in larval salamanders. Oecologia 81:100-103. 
Shutler D., Smith T.G. \& Robinson S.R. 2009. Relationships between leukocytes and Hepatozoon spp. in green frogs, Rana clamitans. J. Wildl. Dis. 45(1):67-72.

Thrall M.A. 2004. Hematology of amphibians, Veterinary Hematology and Clinical Chemistry: text and clinical case presentations. Lippincott Williams and Wilkins, Philadelphia, PA.

Travis J. 1984. Anuran size at metamorphosis: experimental test of a model based on intraspecific competition. Ecology 65:1155-1160.

Thurmond W., Kloas W. \& Hanke W. 1986. Circadian rhythm of interrenal activity in Xenopus laevis. Gen. Comp. Endocrinol. 61:260-271.

Ussing A.P. \& Rosenkilde P. 1995. Effect of induced metamorphosis on the immune system of the Axotil, Ambyostoma mexicanum. Gen. Comp. Endocrinol. 97:308-319.

Wada H. 2008. Glucocorticoids: mediators of vertebrate ontogenetic transitions. Gen. Comp. Endocrinol. 156(3):441-453.

Wang J.H. \& Chang M.H. 1994. Studies on hematology of captive bullfrog, Rana catesbeiana. Coa Fish 46:69-87.

Wendelaar Bonga S.E. 1997. The stress response in fish. Physiol. Reviews $77(3): 592-625$.
Wick G., Hu Y., Schwartz S. \& Kroemer G. 1993. Immunoendocrine communication via the hypothalamo-pituitary adrenal axis in autoimmune disease. Endocrine Reviews 14:539-563.

Woodhams D.C., Ardipradja K., Alford R.A., Marantelli G., Reinert L.K. \& Rollins-Smith L.A. 2007. Resistance to chytridiomycosis varies among amphibian species and is correlated with skin peptide defenses. Animal Conservation 10:409-417.

Wright M.L., Cykowski L.J., Lundrigan L., Hemond K.L., Kochan D.M., Faszewski E.E. \& Anuszewski C.M. 1994. Anterior pituitary and adrenal cortical hormones accelerate or inhibit tadpole hindlimb growth and development depending on stage of spontaneous development or tyroxine concentration in induced metamorphosis. J. Exp. Zoology 270:175188.

Wright K.M. 2001. Amphibian hematology, p.111-122. In: Wright K.M. \& Whitaker B.R. (Eds), Amphibian Medicine and Captive Husbandry. Krieger, Malabar, FL.

Wright M.L., Guertin C.J., Duffy J.L., Szatkowski M.C., Visconti R.F. \& Alves C.D. 2003. Developmental and diel profiles of plasma corticosteroids in the bullfrog, Rana catesbeiana. Comp. Biochem. Physiol. A 135:585-595.

Zar J.H. 1999. Biostatical Analysis. $4^{\text {th }}$ ed. Prentice Hall, New Jersey. 663p. 